DOI: https://doi.org/10.24297/jssr.v14i0.8496

\title{
The Impact of an Educational Support Program on Formal Caregivers of Elderly People with Dementia in the Institutional Context
}

\author{
Alexandra Mónica Almeida Miquelino Miranda ${ }^{1}$, Maria Isabel Correia Dias ${ }^{2}$, Alexandra Cristina Ramos da \\ Silva Lopes Gunes ${ }^{3}$ \\ alexandra.m.miranda@gmail.com ${ }^{1}$, mdias@letras.up.pt ${ }^{2}$, aslopes@letras.up.pt ${ }^{3}$ \\ Institute of Sociology, University of Porto, Portugal
}

\begin{abstract}
With the aging of the population and the increase of social services tackling their needs, it has been increasing the concern about the qualifications of formal caregivers, with the aim of continuous improvement of the quality of the services they provide to the elderly. The goal of this study is to evaluate the impact of an educational support program on formal caregivers of elderly people with dementia in an institutional context. It follows a quasi-experimental design where the 97 formal caregivers that have participated in the study came from two different institutions. They were randomly selected to participate in an educational support program on dementia, with two groups formed: a control group and an experimental group. Pre and post training tests were used to evaluate knowledge and perceptions about dementia in old age. Findings suggest that the impact of the educational support program has improved knowledge and perceptions about dementia in old age among formal caregivers.
\end{abstract}

Keywords: Dementia; Formal Caregivers; Educational Support Program; Old Age

\section{Resumen}

Con el envejecimiento de la población y el aumento de las respuestas sociales, hemos asistido a una creciente preocupación por la formación de auxiliares formales, con el objetivo de mejorar continuamente la cualidad de los servicios que prestan a las personas mayores. Este estudio tiene como objetivo evaluar el impacto de un programa de apoyo educativo para cuidadores formales de personas mayores con demencia, en un contexto institucional. Es un estudio de diseño cuasi experimental en el que participaron 97 asistentes de acción directa, que luego fueron seleccionados al azar para un programa de apoyo educativo sobre la demencia. Hemos trabajado con dos grupos: un grupo de control y un grupo experimental. Los principales resultados mostraron, de manera relativamente confiable, el impacto del programa de apoyo educativo implementado para cuidadores formales de personas mayores con demencia tanto en su conocimiento como en las percepciones que tienen sobre la demencia .

Palabras Ilave: demencia; cuidadores formales; programa de apoyo educativo; personas mayores

\section{Resumo}

Com o envelhecimento da população e o aumento das respostas sociais, cada vez mais tem crescido a preocupação com a formação dos auxiliares formais, com o intuito de melhoria contínua da qualidade dos serviços que prestam aos idosos. O presente estudo pretende avaliar o impacto de um programa de apoio educativo a cuidadores formais de pessoas idosas com demência, em contexto institucional. Trata-se de um estudo com desenho quase-experimental, no qual participaram 97 auxiliares de ação direta, que foram posteriormente selecionados aleatoriamente para um programa de apoio educativo sobre demência, tendo-se constituído dois grupos: um grupo de controlo e um grupo experimental. Os principais resultados mostraram, de forma relativamente fiável, o impacto do programa de apoio educativo implementado aos cuidadores formais de pessoas idosas com demência. 
Palavras-chave: demência; auxiliares de ação direta; programa de apoio educativo; idosos

\section{Introduction}

With aging, we witness profound transformations in the health of the human being, which has led to an increase in the average life expectancy and has posed one of the greatestchallenges to current public health (Lima-Costa $\&$ Veras, 2003). Many older people become more dependent, have chronic diseases and experience a decrease in function, which leads them to feelings of loneliness, isolation and frailty (Martins, 2006). Thus, aging cannot be seen as a problem of the individual or his family, but rather as a public problem, so that the support for the elderly, when there is no informal care network (e.g., family, friends, neighbors), falls on the formal system of care (Gomes \& Mata, 2012; Jacob, 2012; Mata \& Rodriguez, 2012; Pereira, 2012a, b).

Thus, institutionalization arises, both for the family and for the elderly, as a last resource, and should be understood as a double process: the access to social services of elderly admitted to retirement homes, nursing homes and similar institutions, where they receive assistance, and as an experience of loss, represented by depressive states, indicating how elderly can experience the institutionalized life (Pimentel, 2005). The professionals who provide these institutional services - designated by formal caregivers - offer physical and psychological support to the elderly (Vigia, 2012), assistance to support the temporary or permanent loss of function (Pereira, 2012b), stressing the need for continuous education and geared to the needs and daily realities experienced (e.g., Almeida, 2014; 2013 Beringuilho; Carvalho, 2012; Conceição, 2012; Dzhankarashvili, 2017; Ferreira, 2014b; Loureiro, 2016; Margarido, 2016; Pereira \& Marques, 2014; Rodrigues, 2014), especially when facing elderly people with dementia (e.g., Almeida 2014; Cepeda 2013; Wedge, 2012). The formal caregiver is a professional who should display basic competences, such as understanding the needs of the elderly, knowing how to distinguish them, knowing how to deal with diseases and their cognitive symptoms or the social, personality or family and contextual problems. However, the assistance with activities of daily living such as hygiene and feeding are also interventions that are part of the role of formal caregivers for the elderly (Corte, Pereira, \& Marques, 2014). Following this line of thought, and considering the crucial role that education plays in the quality of care delivered to the elderly, the study aimed to evaluate the impact of an educational support program on formal caregivers of elderly people with Dementia, in an institutional context.

\section{Methods}

\section{Participants}

The study was presented in a total of 5 institutions, represented by one or more board of directors, all based in the North, with three being Private Institutions of Social Solidarity (IPSS's) and two with a private business character. It should be noted that one of the institutions expressed lack of interest in participating in the study. Therefore, the same was completed in two IPSS's and two private institutions and they will not be identified because they requested anonymity.

After being granted permission to carry out the study, a second contact was made through a meeting with the potential participants, where they were informed about the nature and objectives of the study, promis ed confidentiality after participation in the study, as well as the right to refuse without prejudice. The professionals who agreed to participate, as well as a member of the management team, were presented with possible dates for the completion of the data collection protocols and subsequently the dates for the completion of the education. They were also informed that of the total number of participants, one group would be randomly selected to be the target of the intervention to participate in the education program, thus forming two groups, one control group and an experimental group.

\section{Procedure}

After being granted authorization to perform the study, the intervention was structured in three moments; Moment I, completion of the data collection protocol for all participants, moment II, implementation of the 
education program to the experimental group and moment III, completion of the questionnaire about concepts and knowledge about dementia, to all participants in moments I and II. After data collection was carried out with all participants, 97 formal caregivers and the random selection, the intervention was initiated with the educational program, and was called "Caring for the elderly with dementia: challenges, perceptions and knowledge" and applied only to the experimental group, represented by 50 direct action caregivers that accepted, randomly, to participate in the educational support program. This program was developed by us, based on the literature review conducted, aiming to respond to the main challenges identified in the various investigation studies consulted.

Some fundamental components were considered, namely: the elderly person and the formal caregiver; dementia; caring for elderly with dementia; problem prevention and dealing with elderly with dementia. This program was designed on the basis of the following objectives: knowing and describing some concepts and definitions; to identify the needs of elderly people with dementia; to analyze strategies in the direct care to elderly persons with dementia; to analyze the relationship education/care delivery; to evaluate the impact of the Program. The Educational Program was completed in 2 sessions, lasting 1:30h each, not initially foreseen, as it was intended that the sessions do not exceed 60 minutes, not having been possible for reasons not controllable, such as the availability of the participants and the institutions themselves. After the collection of all the questionnaires, they were validated through the use of an attendance sheet and checked to validate their correct and adequate completions, and, subsequently, all data were entered into the statistical software, Package for the Social Sciences ${ }^{\circledR}$ (IBM ${ }^{\circledR}$ SPSS), version 23.0 for Windows.

\section{Results}

The results obtained, which are reflected on table 1, ensure stability in the results, before and after the implementation of the Educational Support Program, in the two contrasting groups, that is, in the control group it is observed significant positive correlations between knowledge and perceptions before $(r=0.727 ; p \leq 0.01)$; between knowledge before and after $(r=0.407 ; p \leq 0.01)$; between the knowledge before and the perceptions after ( $r=0.323 ; p \leq 0.01)$; between perceptions before and knowledge after $(r=0.470 ; p \leq 0.01)$ and between the perceptions before and after the implementation of the Educational Support Program $(r=0.555 ; p \leq 0.01)$ and, in the experimental group, there are significant positive correlations between knowledge and perceptions before the implementation of the Educational Support Program $(r=0.741 ; p \leq 0.01)$; between knowledge before and $\operatorname{after}(r=0.389 ; p \leq 0.01)$; between the knowledge before and the perceptions after $(r=0.433 ; p \leq 0.01)$; between perceptions before and knowledge after $(r=0.281 ; p \leq 0.05)$ and between perceptions before and after $(r=0.280$; $p \leq 0.05$ ). In the first phase of analysis, the goal was to analyze the correlations between the analytical dimensions, before and after the implementation of the educational Support program, in the two contrasting groups.

Table 1. Correlations between the total scores recorded before and after the delivery of the Educational Support Program (knowledge and perceptions), by test group

\begin{tabular}{|c|c|c|c|c|c|}
\hline \multicolumn{6}{|l|}{ Control group } \\
\hline \multicolumn{2}{|c|}{$\begin{array}{l}\text { Total values for knowledge and } \\
\text { perceptions }\end{array}$} & \multicolumn{2}{|c|}{$\begin{array}{l}\text { Before the delivery of the } \\
\text { educational support program }\end{array}$} & \multicolumn{2}{|c|}{$\begin{array}{l}\text { After the delivery of the } \\
\text { educational support program }\end{array}$} \\
\hline & & $\begin{array}{l}\text { Total for } \\
\text { knowledge }\end{array}$ & $\begin{array}{l}\text { Total for } \\
\text { perceptions }\end{array}$ & $\begin{array}{ll}\text { Total } & \text { for } \\
\text { knowledge } & \end{array}$ & $\begin{array}{l}\text { Total for } \\
\text { perceptions }\end{array}$ \\
\hline \multirow{2}{*}{$\begin{array}{l}\text { Before the } \\
\text { delivery of } \\
\text { the } \\
\text { educational }\end{array}$} & $\begin{array}{l}\text { Total } \\
\text { knowledge }\end{array}$ & - & $0,727^{\star}$ & $0,407^{\star}$ & $0,323^{*}$ \\
\hline & $\begin{array}{l}\text { Total } \\
\text { perceptions }\end{array}$ & - & - & $0,470^{*}$ & $0,555^{*}$ \\
\hline
\end{tabular}




\begin{tabular}{|c|c|c|c|c|c|}
\hline \multicolumn{6}{|l|}{$\begin{array}{l}\text { support } \\
\text { program }\end{array}$} \\
\hline \multicolumn{6}{|c|}{ Experimental group } \\
\hline \multirow{2}{*}{\multicolumn{2}{|c|}{$\begin{array}{l}\text { Total values for knowledge and } \\
\text { perceptions }\end{array}$}} & \multicolumn{2}{|c|}{$\begin{array}{l}\text { Before the delivery of the } \\
\text { educational support program }\end{array}$} & \multicolumn{2}{|c|}{$\begin{array}{l}\text { After the delivery of the } \\
\text { educational support program }\end{array}$} \\
\hline & & $\begin{array}{l}\text { Total for } \\
\text { knowledge }\end{array}$ & $\begin{array}{l}\text { Total for } \\
\text { perceptions }\end{array}$ & $\begin{array}{l}\text { Total for } \\
\text { knowledge }\end{array}$ & $\begin{array}{l}\text { Total for } \\
\text { perceptions }\end{array}$ \\
\hline \multirow{2}{*}{$\begin{array}{l}\text { Before the } \\
\text { delivery of } \\
\text { the } \\
\text { educational } \\
\text { support } \\
\text { program }\end{array}$} & $\begin{array}{l}\text { Total for } \\
\text { knowledge }\end{array}$ & - & $0,741^{*}$ & $0,389^{*}$ & $0,433^{*}$ \\
\hline & $\begin{array}{l}\text { Total for } \\
\text { perceptions }\end{array}$ & - & - & $0,281^{(+)}$ & $0,280^{(+)}$ \\
\hline
\end{tabular}

When analyzing the mean values obtained at the level of knowledge and perceptions before the delivery of the Educational Support Program (table 2), it is observed that there is no significant effect on most variables sociodemographic variables considered, except for the variable educational qualifications, where greater knowledge is verified ( $t=7.954 ; p=0.005)$ and better perceptions $(t=4.783 ; p=0.004)$ among caregivers with higher qualifications; more knowledge with those who worked for less than 12 months ( $t=3.46 ; p=0.020$ ); with those who don't work nights $(t=-2.669 ; p=0.040)$; who are not informal caregivers $(t=2.219 ; p=0.029)$ and higher knowledge $(t=-2.397 ; p=0.019)$ and better perceptions $(t=-2.735 ; p=0.008)$, with those part of the experimental group.

Table 2. Mean values for the knowledge and perceptions, before the delivery of the Educational Support Program

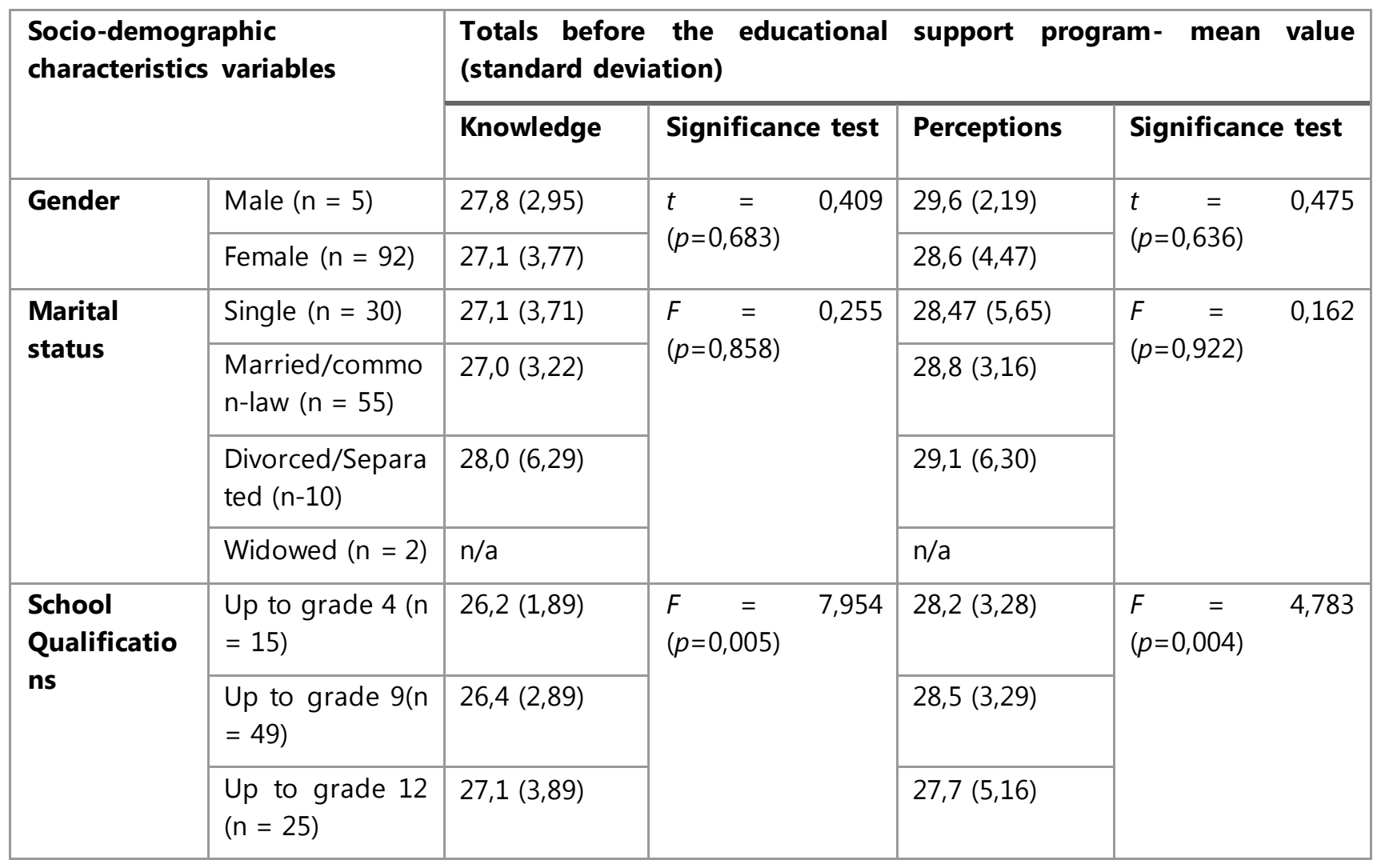




\begin{tabular}{|c|c|c|c|c|c|c|c|}
\hline & $\begin{array}{l}\text { University level } \\
\text { education }(n= \\
\text { 8) }\end{array}$ & $32,6(5,98)$ & & & $33,9(4,37)$ & & \\
\hline \multirow{2}{*}{$\begin{array}{l}\text { Previously } \\
\text { trained }\end{array}$} & Yes $(n=67)$ & $27,5(4,18)$ & \multirow{2}{*}{$\begin{array}{l}t \quad= \\
(p=0,157)\end{array}$} & \multirow{2}{*}{1,427} & $29,1(4,86)$ & \multirow{2}{*}{$\begin{array}{l}t \quad= \\
(p=0,137)\end{array}$} & \multirow[t]{2}{*}{1,502} \\
\hline & No $(n=30)$ & $26,3(2,25)$ & & & $27,7(2,89)$ & & \\
\hline \multirow[t]{4}{*}{ Seniority } & $\begin{array}{l}<12 \text { months } \\
\text { (no. 19) }\end{array}$ & $28,4(2,39)$ & \multirow{4}{*}{\multicolumn{2}{|c|}{$F=3,46(p=0,020)$}} & $29,8(2,54)$ & \multirow[t]{4}{*}{$\begin{array}{l}F \quad= \\
(p=0,238)\end{array}$} & \multirow[t]{4}{*}{1,433} \\
\hline & $\begin{array}{l}12 \text { to } 24 \text { months } \\
\text { (no. } 17 \text { ) }\end{array}$ & $26,7(3,52)$ & & & $28,0(5,20)$ & & \\
\hline & $\begin{array}{l}24 \text { to } 36 \text { months } \\
\text { (no. } 15 \text { ) }\end{array}$ & $25,3(2,53)$ & & & $27,0(3,55)$ & & \\
\hline & $\begin{array}{l}>\quad 36 \text { months } \\
\text { (no. 46) }\end{array}$ & $27,8(3,72)$ & & & $29,0(4,79)$ & & \\
\hline \multirow[t]{2}{*}{ Previous job } & $\begin{array}{l}\text { Similar area (n- } \\
\text { 29) }\end{array}$ & $26,5(3,31)$ & \multirow[t]{2}{*}{$\begin{array}{l}t \quad= \\
(p=0,288)\end{array}$} & \multirow[t]{2}{*}{$-1,068$} & $28,2(3,76)$ & \multirow[t]{2}{*}{$\begin{array}{l}t= \\
(p=0,512)\end{array}$} & \multirow[t]{2}{*}{$-0,658$} \\
\hline & $\begin{array}{l}\text { Other area }(n= \\
68)\end{array}$ & $27,4(3,87)$ & & & $28,9(4,38)$ & & \\
\hline \multirow[t]{2}{*}{$\begin{array}{l}\text { Contract } \\
\text { Type* }\end{array}$} & $\begin{array}{l}\text { Contract without } \\
\text { term }(n=72)\end{array}$ & $26,9(4,05)$ & \multirow[t]{2}{*}{$\begin{array}{l}t \quad= \\
(p=0,332)\end{array}$} & \multirow[t]{2}{*}{$-0,974$} & $28,5(4,84)$ & \multirow[t]{2}{*}{$\begin{array}{l}t \quad= \\
(p=0,519)\end{array}$} & \multirow[t]{2}{*}{$-0,648$} \\
\hline & $\begin{array}{l}\text { Contract with } \\
\text { term }(n=24)\end{array}$ & $27,7(2,24)$ & & & $29,1(2,33)$ & & \\
\hline \multirow[t]{2}{*}{ Schedule } & Fixed $(n=25)$ & $27,9(2,58)$ & \multirow{2}{*}{\multicolumn{2}{|c|}{$t=1,23(p=0,407)$}} & $29,3(6,01)$ & \multirow{2}{*}{$\begin{array}{l}t \quad= \\
(p=0,407)\end{array}$} & \multirow[t]{2}{*}{0,833} \\
\hline & Rotating $(\mathrm{n}-72)$ & $28,4(4,62)$ & & & $28,5(4,38)$ & & \\
\hline \multirow[t]{2}{*}{ Night Work } & Yes $(n=56)$ & $26,2(2,58)$ & \multirow{2}{*}{\multicolumn{2}{|c|}{$\begin{array}{l}t \quad= \\
(p=0,040)\end{array}$}} & $27,9(3,08)$ & \multirow{2}{*}{\multicolumn{2}{|c|}{$t=-1,92(p=0,069)$}} \\
\hline & No $(n=41)$ & $28,4(3,72)$ & & & $29,8(4,38)$ & & \\
\hline \multirow{2}{*}{$\begin{array}{l}\text { Informal } \\
\text { Caregiver }\end{array}$} & Yes $(n=17)$ & $25,4(2,09)$ & \multirow{2}{*}{$\begin{array}{l}t \quad= \\
(p=0,029)\end{array}$} & \multirow{2}{*}{2,219} & $27,4(3,89)$ & \multirow{2}{*}{$\begin{array}{l}t \quad= \\
(p=0,186)\end{array}$} & \multirow[t]{2}{*}{1,332} \\
\hline & No $(n=80)$ & $27,5(3,88)$ & & & $29,0(4,45)$ & & \\
\hline \multirow[t]{2}{*}{ Test group } & Control $(n=47)$ & $26,2(2,75)$ & \multirow{2}{*}{$\begin{array}{l}t \quad= \\
(p=0,019)\end{array}$} & \multirow{2}{*}{$-2,397$} & $27,5(3,44)$ & \multirow{2}{*}{$\begin{array}{l}t \quad= \\
(p=0,008)\end{array}$} & \multirow[t]{2}{*}{$-2,735$} \\
\hline & $\begin{array}{l}\text { Experimental } \\
(n=50)\end{array}$ & $28,0(4,30)$ & & & $29,8(4,87)$ & & \\
\hline
\end{tabular}

* 1 case declared to have service delivery contract, being omitted because it is only 1 occurrence

Analyzing the mean values of knowledge and perceptions after the implementation of the Educational Support Program (table 3), it is observed that there is no significant effect of the sociodemographic variables considered, except for the test group, which shows that the experimental group presents with significantly more knowledge $(t=-23.27 ; p=0.005)$ and better perceptions about dementia $(t=-20.211 ; p=0.005)$, after the delivery of the Educational Support Program, when compared to the control group. 
Table 3. Mean values for the knowledge and perceptions, after the delivery of the Educational Support Program

\begin{tabular}{|c|c|c|c|c|c|c|}
\hline \multicolumn{2}{|c|}{$\begin{array}{l}\text { Socio-demographic characteristics } \\
\text { variables }\end{array}$} & \multicolumn{2}{|c|}{$\begin{array}{l}\text { Totals after the Educational } \\
\text { (standard deviation) }\end{array}$} & \multicolumn{3}{|c|}{ Support Program - mean value } \\
\hline & & Knowledge & $\begin{array}{l}\text { Significance } \\
\text { test }\end{array}$ & Perceptions & $\begin{array}{l}\text { Significar } \\
\text { test }\end{array}$ & nce \\
\hline \multirow[t]{2}{*}{ Gender } & Male $(n=5)$ & $26,6(3,13)$ & \multirow{2}{*}{$\begin{array}{l}t=-1,652 \\
(p=0,102)\end{array}$} & $27,2(3,49)$ & \multirow{2}{*}{$\begin{array}{l}t= \\
(p=0,172)\end{array}$} & $-1,375$ \\
\hline & Female $(n=92)$ & $31,5(6,63)$ & & $31,5(6,98)$ & & \\
\hline \multirow{4}{*}{$\begin{array}{l}\text { Marital } \\
\text { status }\end{array}$} & Single $(n=30)$ & $30,5(6,62)$ & \multirow{4}{*}{$\begin{array}{l}F=0,194 \\
(p=0,900)\end{array}$} & $30,6(7,25)$ & \multirow{4}{*}{$\begin{array}{l}F= \\
(p=0,925)\end{array}$} & 0,157 \\
\hline & $\begin{array}{l}\text { Married/Common- } \\
\text { law }(\mathrm{n}=55)\end{array}$ & $31,7(6,49)$ & & $31,6(6,75)$ & & \\
\hline & $\begin{array}{l}\text { Divorced/Separated } \\
(n-10)\end{array}$ & $31,5(7,67)$ & & $31,8(7,53)$ & & \\
\hline & Widowed $(n=2)$ & $\mathrm{n} / \mathrm{a}$ & & $\mathrm{n} / \mathrm{a}$ & & \\
\hline \multirow[t]{4}{*}{$\begin{array}{l}\text { Academic } \\
\text { qualifications }\end{array}$} & $\begin{array}{l}\text { Up to grade } 4(n= \\
15)\end{array}$ & $30,0(6,71)$ & \multirow[t]{4}{*}{$\begin{array}{l}F=0,972 \\
(p=0,409)\end{array}$} & $30,1(7,47)$ & \multirow[t]{4}{*}{$\begin{array}{l}F= \\
(p=0,538)\end{array}$} & 0,728 \\
\hline & $\begin{array}{l}\text { Up to grade } 9(n= \\
49)\end{array}$ & $31,0(6,10)$ & & $31,0(6,18)$ & & \\
\hline & $\begin{array}{l}\text { Up to grade } 12(n= \\
25)\end{array}$ & $31,5(6,65)$ & & $31,7(7,19)$ & & \\
\hline & $\begin{array}{l}\text { University level } \\
\text { education }(n=8)\end{array}$ & $34,8(8,86)$ & & $34,4(9,29)$ & & \\
\hline \multirow{2}{*}{$\begin{array}{l}\text { Previously } \\
\text { trained }\end{array}$} & Yes $(n=67)$ & $31,7(6,73)$ & \multirow{2}{*}{$\begin{array}{l}t=0,890 \\
(p=0,376)\end{array}$} & $31,8(7,06)$ & \multirow{2}{*}{$\begin{array}{l}t= \\
(p=0,277)\end{array}$} & 1,093 \\
\hline & No $(n=30)$ & $30,4(6,23)$ & & $30,2(6,48)$ & & \\
\hline \multirow{4}{*}{$\begin{array}{l}\text { Seniority in } \\
\text { the } \\
\text { institution }\end{array}$} & $\begin{array}{l}<12 \text { months (no. } \\
\text { 19) }\end{array}$ & $31,4(6,82)$ & \multirow[t]{4}{*}{$\begin{array}{l}F \quad=1,77 \\
(p=0,159)\end{array}$} & $32,4(6,64)$ & \multirow[t]{4}{*}{$\begin{array}{l}F \quad= \\
(p=0,286)\end{array}$} & \multirow[t]{4}{*}{1,278} \\
\hline & $\begin{array}{l}12 \text { to } 24 \text { months } \\
\text { (no. 17) }\end{array}$ & $29,0(6,20)$ & & $29,2(6,70)$ & & \\
\hline & $\begin{array}{l}24 \text { to } 36 \text { months } \\
\text { (no. 15) }\end{array}$ & $29,5(6,57)$ & & $29,6(6,92)$ & & \\
\hline & $\begin{array}{l}>36 \text { months (no. } \\
46)\end{array}$ & $32,7(6,45)$ & & $32,2(7,00)$ & & \\
\hline \multirow[t]{2}{*}{ Previous job } & Similar area $(\mathrm{n}-29)$ & $30,8(6,80)$ & \multirow{2}{*}{$\begin{array}{l}t=-0,517 \\
(p=0,607)\end{array}$} & $30,7(7,28)$ & \multirow{2}{*}{$\begin{array}{l}t= \\
(p=0,566)\end{array}$} & $-0,576$ \\
\hline & Other area $(n=68)$ & $31,5(6,51)$ & & $31,6(6,76)$ & & \\
\hline
\end{tabular}




\begin{tabular}{|c|c|c|c|c|c|}
\hline \multirow[t]{2}{*}{$\begin{array}{l}\text { Contract } \\
\text { Type* }\end{array}$} & $\begin{array}{l}\text { Contract without } \\
\text { term }(n=72)\end{array}$ & $31,4(6,73)$ & \multirow[t]{2}{*}{$\begin{array}{l}\mathrm{t}=0,493 \\
(p=0,623)\end{array}$} & $31,2(7,20)$ & \multirow[t]{2}{*}{$\begin{array}{l}\mathrm{t}=-0,051 \\
(p=0,959)\end{array}$} \\
\hline & $\begin{array}{l}\text { Contract with term } \\
(n=24)\end{array}$ & $30,6(6,08)$ & & $31,3(5,99)$ & \\
\hline \multirow[t]{2}{*}{ Schedule } & Fixed $(n=25)$ & $32,2(7,14)$ & \multirow{2}{*}{$\begin{array}{l}\mathrm{t}=0,767 \\
(p=0,445)\end{array}$} & $32,3(7,27)$ & \multirow{2}{*}{$\begin{array}{l}\mathrm{t}=0,849 \\
(p=0,398)\end{array}$} \\
\hline & Rotating (n-72) & $31,0(6,39)$ & & $31,0(6,78)$ & \\
\hline \multirow[t]{2}{*}{ Night Work } & Yes $(n=56)$ & $30,3(6,23)$ & \multirow{2}{*}{$\begin{array}{l}\mathrm{t}=-1,808 \\
(p=0,074)\end{array}$} & $31,6(6,82)$ & \multirow{2}{*}{$\begin{array}{l}\mathrm{t}=-1,726 \\
(p=0,088)\end{array}$} \\
\hline & No $(n=41)$ & $32,7(6,87)$ & & $29,9(7,31)$ & \\
\hline \multirow{2}{*}{$\begin{array}{l}\text { Informal } \\
\text { caregiver }\end{array}$} & Yes $(n=17)$ & $29,8(6,83)$ & \multirow{2}{*}{$\begin{array}{l}t=1,012 \\
(p=0,314)\end{array}$} & $29,9(7,31)$ & \multirow{2}{*}{$\begin{array}{l}t=0,900 \\
(p=0,370)\end{array}$} \\
\hline & No $(n=80)$ & $31,6(6,52)$ & & $31,6(6,82)$ & \\
\hline \multirow[t]{2}{*}{ Test group } & Control $(n=47)$ & $25,1(2,68)$ & \multirow[t]{2}{*}{$\begin{array}{l}t=-23,327 \\
(p<0,005)\end{array}$} & $24,9(3,69)$ & \multirow[t]{2}{*}{$\begin{array}{l}t=-20,211 \\
(p<0,005)\end{array}$} \\
\hline & $\begin{array}{l}\text { Experimental } \\
(\mathrm{n}=50)\end{array}$ & $37,1(2,42)$ & & $37,3(2,20)$ & \\
\hline
\end{tabular}

* 1 case declared to have service delivery contract, being omitted because it is only 1 occurrence

As we detail the evidence of the benefits with the delivery of the Educational Support Program, it was possible to note that, in the control group, there is a slight decline in knowledge and perceptions after the delivery of the program, while a clear increase in the experimental group is observed, being those differences statistically significant.

Changes in average test group scores on knowledge and perception scale

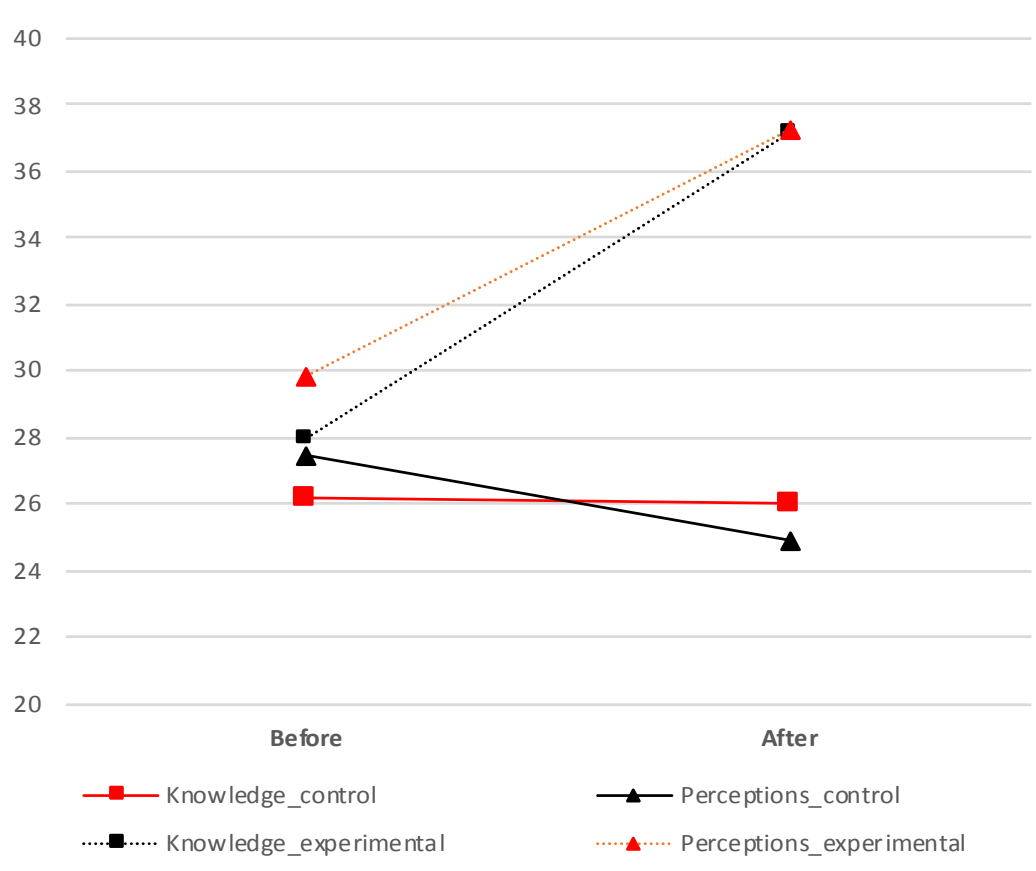


Graph 1. Change in the mean results of the test groups, in the dimensions under analysis (knowledge and perceptions)

\section{Discussion}

Analyzing the mean values of knowledge and perceptions before the delivery of the Educational Support Program, the main results showed that there was no significant effect on most sociodemographic variables considered, despite some variables (e.g., school qualifications, seniority, night work, informal caregivers and test group), presenting small variations, not very relevant. When, however, the mean values of knowledge and perceptions are compared after the delivery of the Educational Support Program, it is observed that there are no statistically significant differences in the sociodemographic variables considered, with the exception of the test group, that shows an absolutely overwhelming difference in knowledge and perceptions, between the control group and the experimental group, in favor of the latter.

The results reinforce the importance of education of all formal caregivers, and more specifically, the direct action caregivers, because it is through education that learning capacities, skills and knowledge to deal with the elderly occurs, reflecting on the professional performance. In fact, education enhances productivity, improves motivation and participation, facilitates internal communication, contributes to the immediate resolution of problems of everyday life, as well as positively influences the psychological well-being of formal caregivers and the elderly, as well as the quality of the care provided (Sousa, 2011). Nevertheless, these results show that it is possible to change the level of knowledge and perceptions after the implementation of an Educational Support Program, as several studies have sustained (e.g., Oak, 2012, 2016; Coffey, 2004; Fitzpatrick \& Roberts, 2004; Lerner et al., 2010), and professionals who are not adequately trained feel insecure in the care they provide (Barbosa et al., 2011; Lerner et al., 2010). In fact, studies have shown the lack of knowledge of direct action caregivers (e.g., Carneiro et al., 2009; Conceição, 2012; Fernandes et al., 2010; Kuske et al., 2007) and the challenges that it poses in their work (Ferreira, 2012; Garrido, 2017). It is in this context that the gerontology professional must act, promoting the dissemination of information to all the professionals who care for the elderly. In the specific case of dementia, it is essential that direct action car egivers have consistent and congruent information about the disease, differentiation of different types and associated aspects, so that its practice can be adjusted to the needs of these elderly (Sousa et al., 2007). Therefore, it is believed that if there is an improvement in the level of knowledge and perceptions, they ultimately influence the level of quality of services delivered (Glaister \& Blair, 2008; Maas et al., 2008; Smith et al., 2005). In this context, it is important to stress the need for the development of intervention programs with formal caregivers who aim not only to promote knowledge and specific competences in the care of dementia, but also the development of strategies that promote the improvement of the quality of care provided to the patients and the welfare of the elderly and their caregivers (Pereira \& Marques, 2014). The results are also encouraging for the work of gerontologists, who should focus on the dissemination of these programs to all formal caregivers, so that the quality of the service provided can be improved. To this end, it is important to consider dementia as a political priority and develop strategic plans with the provision of support services tailored to the specific needs of people with dementia and their families; develop specific training programs for formal caregivers to improve the quality of care provided to the person with dementia and reduce the high burden and stress of caregivers; support the development of research in the broad spectrum of dementia; and develop longer-term care models that are more integrated, flexible and adapted to the different needs of people with dementia. In this respect, the present study is equally important as it seeks to bridge the gaps in research with these professionals, despite recognized as fundamental in the promotion of the quality of life of the elderly. It assumes greater importance in the comprehension of dementia, as a neurovegetative condition affecting the elderly population. Despite considering the positive aspects of the present study, one could not fail to reflect on its main limitations. One of them refers to the small sample size that does not allow a generalization of the results and conditioned, in a certain way, the statistical options performed. 


\section{References}

1. Almeida, R. (2014). Representações sociais do idoso institucionalizado e influência na comunicação dos profissionais ajudantes de ação direta. Dissertação de Mestrado. Castelo Branco: Escola Superior de Educação do Instituto Politécnico de Castelo Branco.

2. Barbosa, A., Cruz, J., Figueiredo, D., Marques, A., \& Sousa, L. (2011). Cuidar de idosos com demência em instituições: Competências, dificuldades e necessidades percecionadas pelos cuidadores formais. Psicologia, Saúde \& Doenças, 12(1), 119-129.

3. Carneiro, B., Pires, E., Filho, A., \& Guimarães, E. (2009). Perfil dos cuidadores de idosos de instituições de longa permanência e a prevalência de sintomatologia dolorosa. ConScientiae Saúde, 8(1), 75-82.

4. Carvalho, A. (2012). Ajudantes de ação direta: perceções sobre formação profissional e impacto da formação na prestação de cuidados a idosos dependentes internados. Dissertação de Mestrado. Lisboa: Universidade Nova de Lisboa.

5. Carvalho, N. (2016). A importância da realização de atividades no processo do envelhecimento ativo de idosos institucionalizados. Dissertação de Mestrado. Braga: Universidade Católica Portuguesa.

6. Cepeda, A. (2013). Cuidadores de pacientes com demência: A influência da doença na saúde mental dos cuidadores. Dissertação de Mestrado. Vila Real: Universidade de Trás-os-Montes e Alto Douro.

7. Conceição, J. (2012). Envelhecimento de idosos institucionalizados: Formação de auxiliares de ação direta na associação casapiana de solidariedade. Dissertação de Mestrado. Lisboa: Universidade Lusófona de Humanidades e Tecnologias Faculdade de Ciências Sociais e Humanas.

8. Coffey, A. (2004). Perceptions of training for care attendants employed in the care of older people. Journal of Nursing Management, 12(5), 322-328.

9. Conceição, J. (2012). Envelhecimento de idosos institucionalizados: Formação de auxiliares de ação direta na associação casapiana de solidariedade. Dissertação de Mestrado. Lisboa: Universidade Lusófona de Humanidades e Tecnologias Faculdade de Ciências Sociais e Humanas.

10. Corte, A., Pereira, S., \& Marques, E. (2014). Dificuldades dos cuidadores formais de idosos institucionalizados. International Journal of Development and Education Psychology, 1(2), 133-140.

11. Cunha, P. (2012). O múltiplo olhar institucional sobre os doentes de Alzheimer. Dissertação de Mestrado. Viseu: Universidade Católica Portuguesa.

12. Dzhankarashvili, C. (2017). Formação de cuidadores - Um passo para a regulamentação da profissão. Dissertação de Mestrado. Porto: Escola Superior de Educação do Instituto Politécnico do Porto.

13. Fernandes, A. (2008). Questões demográficas: Demografia e sociologia da população. Lisboa: Edições Colibri.

14. Fernandes, E., Pavarini, S., Barham, E., Mendiondo, M., \& Luchesi, B. (2010). Envelhecimento e demência: O que sabem os agentes comunitários de saúde? Revista da Escola de Enfermagem USP, 44(3), 782 -788.

15. Ferreira, M. E. (2012). Ser cuidador: Um estudo sobre a satisfação do cuidador formal de idosos. Dissertação de Mestrado. Bragança: Escola Superior de Edução do Instituto Politécnico de Bragança.

16. Fernández-Ballesteros, R. (2002). Social support and quality of life among older people in Spain. Journal of Social Issues, 58(4), 645-659.

17. Ferreira, T. (2014b). O nível de formação dos cuidadores formais de idosos nas instituições do concelho de Celorico de Bastos. Dissertação de Mestrado. Braga: Universidade Católica Portuguesa.

18. Fitzpatrick, J. M., \& Roberts, J. D. (2004). Challenges for care homes: education and training of healthcare assistants. British Journal of Nursing, 8(21), 1258-i126. 
19. Glaister J., \& Blair, C. (2008). Improved education and training for nursing assistants: keys to promoting the mental health of nursing home residents. Issues of Mental Health Nursing, 29(8), 863-872.

20. Garrido, I. (2017). As representações sociais dos cuidadores formais sobre demência. Dissertação de Mestrado. Beja: Escola Superior de Educação do Instituto Politécnico de Beja.

21. Gomes, M., \& Mata, A. (2012). A família provedora de cuidados ao idoso dependente. In F. Pereira (Coord.), Teoria e prática da gerontologia: Um guia para cuidadores de idosos (pp. 163-173). Viseu: Psicosoma.

22. Jacob, L. (2012). Respostas sociais para idosos em Portugal. In F. Pereira (Coord.), Teoria e prática da gerontologia: Um guia para cuidadores de idosos (pp. 129-147). Viseu: Psicosoma.

23. Kuske, B., Hanns, S., Luck, T., Angermeyer, M., Behrens, J., \& Riedel-Heller, S. (2007). Nursing home staff training in dementia care: A systematic review of evaluate programs. International Psychogeriatrics, 19(5), 818-841.

24. Lerner N., Resnick B., Galik, E., \& Russ, K. (2010). Advanced Nursing Assistant Education Program. The Journal of Continuing Education in Nursing, 13, 1-7.

25. Loureiro, M. (2016). Cuidador Formal e a Demência de Alzheimer. Dissertação de Mestrado. Bragança: Escola Superior de Educação do Instituto Politécnico de Bragança.

26. Lima-Costa, M., \& Veras, R. (2003). Saúde pública e envelhecimento. Cadernos de Saúde Pública, 19(3), 700-701. doi.org/10.1590/S0102-311X2003000300001

27. Martins, R. (2006). Envelhecimento e políticas sociais. In Educação, Ciência e Tecnologia (pp. 126-140). Viseu: Instituto Superior Politécnico de Viseu.

28. Mata, A., \& Rodriguez, T. (2012). Autoeficácia do cuidador informal de idosos. In F. Pereira (Coord.), Teoria e prática da gerontologia: Um guia para cuidadores de idosos (pp. 189-204). Viseu: Psicosoma.

29. Margarido, A. (2016). O cuidador formal de idosos: vivência, experiência de burnout e sobrecarga no desempenho da profissão. Dissertação de Mestrado. Lisboa: Faculdade de Psicologia da Universidade de Lisboa.

30. Maas, M., Specht J., Buckwalter K., Gittler, J., \& Bechen, K. (2008). Nursing home staffing and training recommendations for promoting older adults' quality of care and life: Part 2. Increasing nurse staffing and training. Research in Gerontological Nursing, 1(2), 134-152.

31. Pereira, F. (2012a). Sistemas de apoio aos idosos em Portugal. In F. Pereira (Coord.), Teoria e prática da gerontologia: Um guia para cuidadores de idosos (pp. 119-128). Viseu: Psicosoma.

32. Pereira, F. (2012b). A institucionalização do idoso. In F. Pereira (Coord.), Teoria e prática da gerontologia: Um guia para cuidadores de idosos (pp. 149-156). Viseu: Psicosoma.

33. Pereira, S., \& Marques, E. (2014). Dificuldades dos cuidadores formais de idosos institucionalizados. Revista de Psicología, 2, 133-140.

34. Pimentel, L. (2005). O lugar do idoso na família: Contextos e trajetórias. Coimbra: Quarteto.

35. Rodrigues, C. (2014). Perfil dos cuidadores formais de idosos e motivos para a função: Um estudo de caso. Dissertação de Mestrado. Viana de Castelo: Instituto Politécnico de Viana do Castelo.

36. Smith, B., Kerse, N., \& Parsons, M. (2005). Quality of residential care for older people: does education for healthcare assistants make a difference? Journal of the New Zealand Medical Association, 118, 1214.

37. Sousa, L., Mendes, A., \& Relvas, A. P. (2007). Enfrentar a velhice e a doença crónica. Lisboa: Climepsi.

38. Sousa, M. (2011). Formação para a prestação de cuidados a pessoas idosas. Cascais: Princípia.

39. Vigia, M. (2012). Qualidade de vida de cuidadores informais de idosos com demência. Dissertação de Mestrado. Porto: Universidade Fernando Pessoa. 